\title{
Analysis of Carbon Emission Disclosure on Investor Reaction
}

\author{
Nela Safelia, Prof. Haryadi, Enggar Diah Puspa Arum, Afrizal* \\ Faculty of Economics and Business of Jambi University, Jambi, Indonesia.
}

\begin{abstract}
This study aims to analyze and obtain empirical evidence regarding the size of the company, the leverage level, and the profitability of carbon emission disclosure as well as how its impact on investor reaction. The population of this study was manufacturing companies listed on the Indonesia Stock Exchange in the 2016-2018 period. 105 companies were involved as the sample of this study selected using a purposive sampling method. The obtained data were then analyzed using multiple regression analysis and simple regression analysis. The results of this study were company size, leverage level, and profitability simultaneously affect carbon emission disclosure. To be specific, company size does not affect carbon emission disclosure while leverage level negatively affects carbon emission disclosure. Meanwhile, profitability affects carbon emission disclosure, while the effect of carbon emission disclosure does not affect the investor reaction.
\end{abstract}

Keywords: carbon emission disclosure, CSR, investor reaction, profitability, company size, and leverage

DOI: $10.7176 / \mathrm{RJFA} / 11-22-11$

Publication date: November $30^{\text {th }} 2020$

\section{INTRODUCTION}

1.1 Research Background

Nowadays, global warming is an urgent issue that is of concern to the world community. This condition is caused by excessive concentrations of carbon emissions arising from agriculture, land clearing, burning fossil fuels, and other human activities. Some impacts of global warming are the melting of ice peaks which rising the sea levels and earth temperatures and significant climate change. Those impacts might cause harm to the environment and human life. Indonesia as the largest archipelago country in the world has the second-longest coastline in the world which is very vulnerable to the impacts of global warming and climate change.

The problem of climate change and concern over natural disasters are environmental phenomena that often occur in the last years. For example, the occurrence of land fires in Jambi, Pekanbaru, Kalimantan, and some parts of Sumatra Island in August and September 2019. Those fires made Indonesia a major source of carbon emissions. Accordingly, business people in Indonesia are required to think about the importance of protecting land in Indonesia to reduce carbon emissions.

Global warming and climate change have become increasing problems threatening the future of the world. In recent years, companies from various countries have increased their disclosure of information on environmental issues (Prado-Lorenzo et al., 2009), taking into account forests, protection of the ozone layer, climate change, water, energy and natural resources, biodiversity, and so on. The most recent problem is climate change.

The problem faced by various countries related to CSR in the field of natural management is global warming. Fortunately, people have realized the importance of protecting the environment. This is evidenced by the signing of the Kyoto Protocol, which is an amendment to the United Nations Framework Convention on Climate Change (UNFCCC).

Law of Republic Indonesia No. 17 of 2004 on the Ratification of the "Kyoto Protocol To The United Nations Framework Convention On Climate Change" proves that the government has played an active role in dealing with this issue. However, even though the Kyoto Protocol on climate change was stipulated in law in 2004, according to data released by the World Resources Institutes (WRI) in 2018, Indonesia was included in 8 countries which contribute two-thirds of global annual greenhouse gas emissions along with Brazil, China, European Union, India, Japan, Mexico, and the United States. The largest greenhouse gas emissions in the world might have a big impact on producing world carbon emissions.

The industry as a producer of carbon emissions is also required to be responsible for reducing carbon emissions from its operations. Therefore, the need for the accounting treatment of the reporting agreement on carbon produced by the company as a result of the activities carried out by the company in its annual report. The company's carbon emission disclosure is expected to prevent and reduce carbon emissions.

Some factors that might affect the company's carbon emission disclosure include company size, leverage, profitability, and others. Previous empirical studies had explored the relationship between carbon emission disclosure and company characteristics such as company size, profitability, leverage, and the age of company and industry (Prado-Lorenzo et al., 2009; Chithambo and Tauringana, 2014; Gonzalez-Gonzalez and Ramírez, 2016). However, there are no consistent results yet from those studies. The carbon emission disclosure is expected to be a consideration for investors in making investment decisions for companies that pay attention to the environment might tend to apply sustainability in their operational activities according to previous studies conducted by Kelvin et al.,2017 and Park et al.,2014. 
Based on the background of the study above, the researchers analyzed the influence of company characteristics on the carbon emission disclosure and its influence on investor reaction in manufacturing companies listed on the Indonesia Stock Exchange.

\subsection{Research Problems}

1. Do company size, leverage level, and profitability simultaneously affect the carbon emission disclosure?

2. Does the company size partially affect carbon emission disclosure?

3. Does the leverage level partially affect the carbon emission disclosure?

4. Does the profitability partially affect the carbon emission disclosure?

5. Does the carbon emission disclosure affect investor reaction?

\section{LITERATURE REVIEW}

\subsection{Investor Reaction}

Investor appreciates the company's Corporate Social Responsibility practices. Through the practice of CSR activities, the investor can assess the sustainability of a company. One of the investor reaction can be seen from the abnormal return (AT) indicator value. Information can be considered useful for the investor if it creates a reaction to make transactions in the capital market. Investor's trust greatly influences the stock market reaction.

Jogiyanto (2015) defines "abnormal return as the difference between actual return and expected return. An abnormal return will be positive if the return obtained is greater than the expected return or calculated return. Meanwhile, the abnormal return will be negative if the return obtained is smaller than the expected return or the calculated return." According to Remirez et al, (2016) and Liesca, et al (2017), carbon emission disclosure might increase the price movement of company shares compared to companies that do not disclose. Moreover, company performance will also increase by disclosing the environmental performance of the company. However, Li Dan $\mathrm{Wu}$ (2017) revealed that carbon emission disclosure does not affect the stock return.

\subsection{Carbon Emission Disclosure}

The company discloses corporate social responsibility in sustainability reporting. Sustainability reporting is a report on economic policy, social environment that affects performance and products in the context of sustainable development. CSR is the seriousness of business ethics to reduce negative impacts and increase positive impacts in company operations for all stakeholders in the economic and social environment to achieve sustainable development goals. The problem faced by various countries related to CSR in the field of natural management is global warming. However, people nowadays have realized the importance of protecting the environment. This is evidenced by the signing of the Kyoto Protocol, an amendment to the United Nations Framework Convention on Climate Change (UNFCCC).

One of the theories used to understand the determinants of environmental and social disclosure is legitimacy theory, which proposes the concept of "social contract" that exists between organizations and society (Choi et al., 2013). As a consequence of increasing attention to environmental issues, the tendency of companies to engage in environmentally responsible practices should also increase. In this case, companies assure stakeholders that their activities are in line with stakeholder expectations regarding carbon emissions to legitimize themselves and to maintain social contracts (Yunus et al., 2016).

\subsection{Company Size}

Large companies receive more attention than small companies such as investors, customers, government, institutions, NGOs, and other stakeholders. Therefore, large companies are expected to disclose more information regarding their environmental activities. Prado-Lorenzo et al. (2009) analyzed the factors that affect the carbon emission disclosure in companies in the US, Australia, Canada, and the EU concluding that the company size has a significant and positive effect on the disclosure of carbon emission information. Gonzalez-Gonzalez and Ramírez (2016) also analyzed the factors that influence a company's decision to disclose carbon information. Their findings suggest that large company size increases carbon emission disclosure, indicating that stakeholder pressure has a significant effect on such disclosure. and Tauringana (2014) also revealed that company size has a significant effect on the carbon emission disclosure in companies listed on the London Stock Exchange.

\subsection{Leverage}

From an agency theory perspective, the amount of leverage is another factor that might influence the disclosure of carbon emission information. In this case, the company with more debt might have greater agency costs for there is a possibility of transfer of wealth from debtholders to stockholders. By increasing the amount of information on social and environmental activities disclosed, companies can reduce their agency costs and possible conflicts of interest between owners and creditors (Prado-Lorenzo et al., 2009). This shows that the debtholder exerts pressure on the company to disclose environmental-related matters to assess its contingent liability. Since 
companies depend on creditors, accordingly they will disclose carbon emissions to meet creditor's expectations (Rankin et al., 2011). In short, leverage is positively related to carbon emission disclosure.

\subsection{Profitability}

Zhang, et al (2013) show that companies with high profitability tend to disclose more carbon emission information, which is good for companies on corporate finances. Companies with high profitability might be able to incur additional costs to pay for expenses related to voluntary reporting and carbon emission disclosure. According to Lorenzo et al, (2009) and Choi et al (2013), profitability affects carbon emission disclosure, while Oyelere et al. (2003) and Marston dan Polei (2004) did not find a significant relationship between the level of carbon emission disclosure and profitability. In this study, profitability was measured using ROA (Return On Total Assets).

\subsection{Previous Studies}

The results of previous studies (Prado-Lorenzo et al. 2009; Luo et al. 2010; Tang and Luo, 2011; GallegoAlvarez,2010; Borghei-Ghomi and Leung 2013; Choi et al. 2013; Eleftheriadis and Anagnostopoulou 2014; Jannah and Muid 2014) found that carbon emission disclosure had a positive effect on company size. Those studies used total assets, sales, and market capitalization to measure company size.

By analyzing the effect of leverage, some studies have found a positive effect on leverage on carbon emission disclosure (Luo et al., 2013; Clarkson et al. 2008), whereas others had found no statistically significant relationship (Oyelere et al., 2003; Gul and Leung, 2004). In short, according to Lorenzo et al, (2009) and Choi et al (2013), profitability affects carbon emission disclosure while Oyelere et al. (2003) and Marston and Polei (2004) did not find a significant relationship between the level of carbon emission disclosure and profitability.

Remirez et al, (2016) and Liesca, et al (2017) argue that disclosing carbon emission information might increase the price movement of company shares compared to companies that do not disclose. Moreover, company performance might also increase by disclosing environmental performance. However, Li Dan Wu (2017) revealed that carbon emission disclosure does not affect the stock return.

\subsection{Research Framework and Model}

Figure 2.1.

\section{Research Framework and Model}

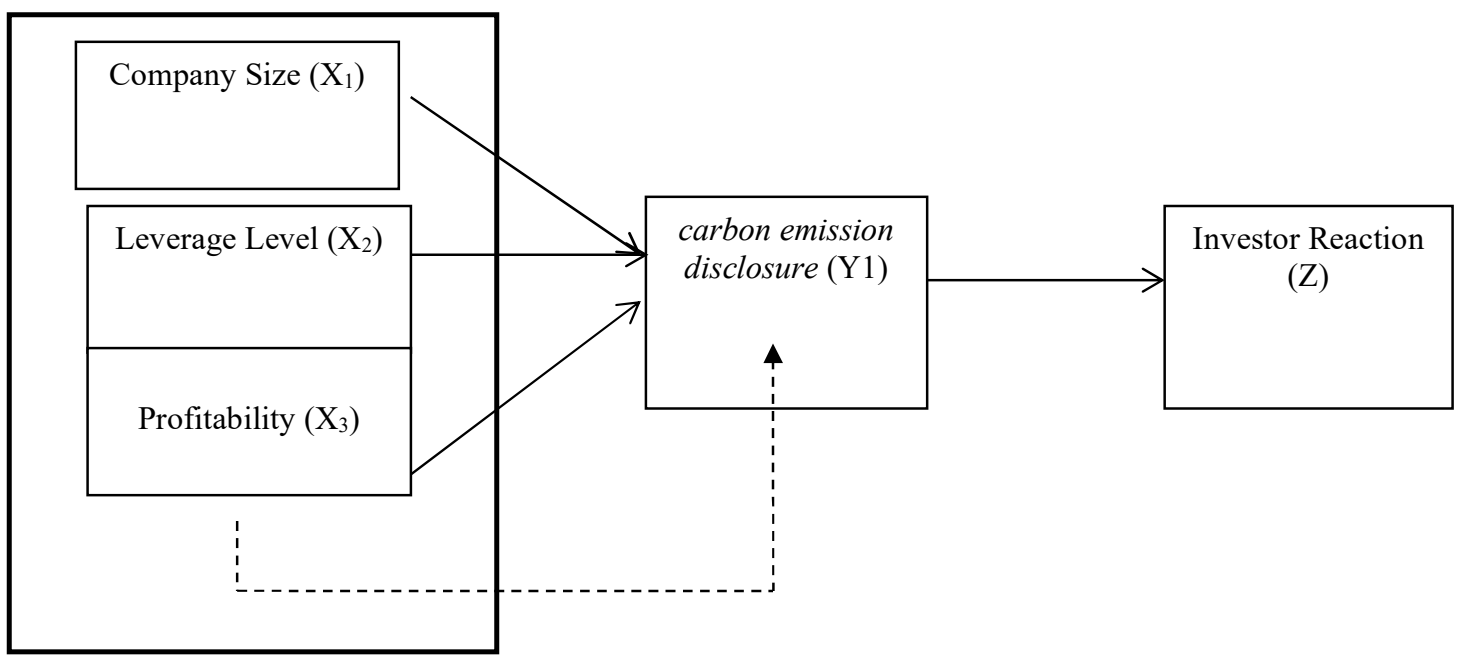

\subsection{Hypotheses}

H1 ; Company size, leverage level, and profitability simultaneously affect the carbon emission disclosure.

H2 ; Company size affects the carbon emission disclosure.

H3 ; Leverage level affects the carbon emission disclosure.

H4 ; Profitability affects the carbon emission disclosure. 


$$
\text { ; Carbon emission disclosure affects investor reaction. }
$$

\section{OBJECTIVES AND BENEFITS}

\subsection{Specific Research Objectives}

The objectives of this study are to analyze and obtain empirical evidence regarding company size, leverage level, and profitability on the carbon emission disclosure and how the impact of the carbon emission disclosure on the investor reaction.

\subsection{Research Benefits}

4. For investors, it is one of the considerations in investing in a company.

5. For companies, this study provides input on the importance of disclosing carbon emission information in financial statements and sustainability reporting. Companies should be more concerned with the social environment in making policies.

6. For the government, this study can be a consideration in making laws. It is expected to consider improving the quality of compiling environmental accounting standards.

\section{RESEARCH METHOD}

\subsection{Research Method and Sources of Data}

This study employed a quantitative method, by collecting the data needed for this study from the companies. To test the hypotheses, the numerical data were processed using statistical methods. The data were in the form of secondary data obtained from the companies' annual reports and reports on stock trading transactions.

\subsection{Population and Sample}

The population of this study was manufacturing companies listed on the Indonesia Stock Exchange in the 2016-2018 period. The companies included as the samples in this study were companies selected on the purposive sampling method, the sampling technique for data sources with certain considerations (Sugiyono, 2011). The criteria used in this study were as follows: Manufacturing companies listed on the Indonesia Stock Exchange for the 2016-2018 period, manufacturing companies that publish annual reports during the 2016-2018 period, and companies that disclose carbon emission information. From 35 companies that meet the criteria, the number was multiplied by 3 years. Thus, 105 companies were included as the sample of this study.

\subsection{Research Variables}

The variables in this study were company size (X1), leverage level (X2), and profitability (X3), while carbon emission disclosure $(\mathrm{Y})$ and investor reaction $(\mathrm{Z})$ were the dependent variables/ endogenous variable. The research operational table is presented in table 4.1 below.

Table 4.1

Operational Variables

\begin{tabular}{|c|c|c|c|}
\hline No. & Variable & Indicator & Scale \\
\hline 1 & $\begin{array}{c}\text { Company Size } \\
\text { (X1) }\end{array}$ & Log Total Assets & Ratio \\
\hline 2 & $\begin{array}{c}\text { Leverage Level } \\
\text { (X2) }\end{array}$ & Debt to Equity Ratio & Ratio \\
\hline 3 & $\begin{array}{c}\text { Profitability } \\
\text { (X3) }\end{array}$ & $\begin{array}{c}\text { Return On Total Assets } \\
\text { (ROA) }\end{array}$ & Ratio \\
\hline 4 & $\begin{array}{c}\text { Carbon Emission } \\
\text { Disclosure (Y) }\end{array}$ & $\begin{array}{c}\text { The number of company } \\
\text { emission carbon disclosures } \\
\text { number of disclosures } \\
\text { expected. }\end{array}$ & Ratio \\
\hline 5 & $\begin{array}{c}\text { Investor Reaction } \\
\text { (Z) }\end{array}$ & $\begin{array}{c}\text { Cumulative Abnormal Return } \\
\end{array}$ & \\
\hline
\end{tabular}




\subsection{Data Analysis Method}

The analysis technique employed in this study was multiple linear regression, which is an analysis used to determine the effect of independent variables on the dependent variable. Before the regression analysis was carried out, the normality test, multicollinearity test, autocorrelation test, and heteroscedasticity test were conducted in advance. The data in this study came from the regression model formed as follows:

$$
\begin{aligned}
& \mathrm{Y}=\mathrm{a}+\mathrm{b} 1 \mathrm{X} 1+\mathrm{b} 2 \mathrm{X} 2+\mathrm{b} 3 \mathrm{X} 3+\mathrm{e} \\
& \mathrm{Z}=\mathrm{a}+\mathrm{b} 1 \mathrm{Y}+\mathrm{e} \\
& \text { Description : } \\
& \text { Y = carbon emission disclosure } \\
& \text { a } \quad=\text { constant } \\
& \mathrm{b} 1-\mathrm{b} 3=\text { regression coefficient } \\
& \mathrm{X} 1=\text { company size } \\
& \mathrm{X} 2=\text { leverage level } \\
& \mathrm{X} 3=\text { profitability } \\
& \mathrm{Z} \quad=\text { investor reaction } \\
& \text { e } \quad=\text { standard error }
\end{aligned}
$$

\section{RESULTS AND DISCUSSION}

\subsection{Results of Descriptive Statistical Analysis}

The results of descriptive statistical test data in this study can be seen in Table 5.1 below:

\section{Table 5.1}

Descriptive Analysis

Descriptive Statistics

\begin{tabular}{|l|c|c|c|c|c|}
\hline & $\mathrm{N}$ & Minimum & Maximum & Mean & Std. Deviation \\
\hline RI_Z & 105 & -0.09 & 0.28 & 0.0197 & 0.06348 \\
UP_X1 & 105 & 25.80 & 32.20 & 28.8728 & 1.45664 \\
TL_X2 & 105 & 0.16 & 7.50 & 1.2100 & 1.23715 \\
P_X3 & 105 & -0.09 & 0.53 & 0.0921 & 1.11522 \\
CED_Y & 105 & 0.06 & 0.94 & 0.3364 & 1.18892 \\
Valid N (listwise) & 105 & & & & \\
\hline
\end{tabular}

Source: Secondary data processed,2020

The results of data processing presented in table 5.1 indicate that the number of samples used in this study was 105 samples. The investor reaction variable had a minimum score of -0.09 and a maximum score of 0.28 . Meanwhile, the mean reaction score of investors was 0.0197 with a standard deviation of 0.06348 . The company size variable had a minimum score of 25.80 and a maximum score of 32.20 . The average score of the company size variable was 28.8728 with a standard deviation of 1.45664 . The leverage level variable had a minimum score of 0.16 and a maximum score of 7.50. The average score of the leverage level was 1.2100 with a standard deviation of 1.23715. The profitability variable had a minimum score of -0.09 and a maximum score of 0.53 . Its average value was 0.0921 with a standard deviation of 1.11522 . Moreover, it can be inferred that the amount of carbon emission disclosure of manufacturing companies listed on the IDX for the 2016-2018 period was between 0.06 and 0.94 with a mean score of 0.3364 and a standard deviation of 1.18892.

\subsection{Multiple Linear Regression Analysis}

The results of multiple linear regression analysis can be seen in the following table: 
Table 5.2

Results of Multiple Linear Regression Analysis

\begin{tabular}{|c|c|c|c|c|c|c|}
\hline \multirow{2}{*}{\multicolumn{2}{|c|}{ Model }} & \multicolumn{2}{|c|}{$\begin{array}{l}\text { Unstandardized } \\
\text { Coefficients }\end{array}$} & \multirow{2}{*}{$\begin{array}{c}\begin{array}{c}\text { Standardized } \\
\text { Coefficients }\end{array} \\
\text { Beta }\end{array}$} & \multirow{2}{*}{$\mathrm{t}$} & \multirow{2}{*}{ Sig. } \\
\hline & & B & $\begin{array}{l}\text { Std. } \\
\text { Error }\end{array}$ & & & \\
\hline & (Constant) & -0.284 & 0.340 & & -0.834 & 0.406 \\
\hline & UP_X1 & 0.022 & 0.012 & 0.169 & 1.853 & 0.067 \\
\hline & TL_X2 & $\begin{array}{r}- \\
0.040\end{array}$ & 0.014 & -0.262 & -2.855 & 0.005 \\
\hline & P_X3 & 0.386 & 1.151 & 0.236 & 2.566 & 0.012 \\
\hline
\end{tabular}

a. Dependent Variable: CED

Source: Data processed using SPSS 22

The above table can be made a multiple regression equatioon as follows:

$$
\mathrm{CED}=-0.283+0.022 \mathrm{SIZE}-0.040 \mathrm{DER}+0.386 \mathrm{ROA}+\mathrm{e}
$$

\subsection{Results of Hypotheses Testing}

Simultaneous test results (F-Test)

Table 5.3.

F Statistic Test Results

ANOVA $^{\mathrm{a}}$

\begin{tabular}{|c|c|c|c|c|c|c|}
\hline \multicolumn{2}{|l|}{ Model } & $\begin{array}{l}\text { Sum of } \\
\text { Squares }\end{array}$ & $\mathrm{df}$ & $\begin{array}{c}\text { Mean } \\
\text { Square }\end{array}$ & $\mathrm{F}$ & Sig. \\
\hline & Regression & 0.624 & 3 & 0.208 & 6.808 & $0.000^{\mathrm{b}}$ \\
\hline 1 & Residual & 3.088 & 101 & 0.031 & & \\
\hline & Total & 3.712 & 104 & & & \\
\hline
\end{tabular}

The F-test results above show that the significance value of the test was $0.000<0.05(\alpha=5 \%)$. This proves that the variables of company size, leverage level, and profitability simultaneously affect CED (H1 is accepted).

\section{Results of the partial test (t-test)}

The following table presents the results of the test for the significance of individual parameters ( $\mathrm{t}$ statistic test), as follows:

Tabel 5.4

Hasil Uji Model Statistik (Uji t) Coefficients ${ }^{\mathrm{a}}$

\begin{tabular}{|c|c|c|c|c|c|c|}
\hline \multirow{2}{*}{\multicolumn{2}{|c|}{ Model }} & \multicolumn{2}{|c|}{$\begin{array}{l}\text { Unstandardized } \\
\text { Coefficients }\end{array}$} & \multirow{2}{*}{$\begin{array}{c}\begin{array}{c}\text { Standardized } \\
\text { Coefficients }\end{array} \\
\text { Beta }\end{array}$} & \multirow{2}{*}{$\mathrm{t}$} & \multirow{2}{*}{ Sig. } \\
\hline & & B & $\begin{array}{l}\text { Std. } \\
\text { Error }\end{array}$ & & & \\
\hline & (Constant) & -0.284 & 0.340 & & -0.834 & 0.406 \\
\hline & UP_X1 & 0.022 & 0.012 & 0.169 & 1.853 & 0.067 \\
\hline & TL_X2 & -0.040 & 0.014 & -0.262 & -2.855 & 0.005 \\
\hline & $P \_X 3$ & 0.386 & 1.151 & 0.236 & 2.566 & 0.012 \\
\hline
\end{tabular}

a. Dependent Variable: CED

Source: Data processed using SPSS 22

The table above shows the significance value of the company size variable on emission disclosure was 
$0.067>0.05(\alpha=5 \%)$. This finding explains that company size does not affect emission disclosure (H2 is accepted). The results of this study in contrast to previous studies (Rankin et al., 2011; Choi et al., 2013; Gonzalez-Gonzalez and Ramírez, 2016; Yunus et al., 2016; Ben-Amar et al., 2017).

The test results show that the leverage level had a negative effect with a significance value of $0.005<$ 0.05. Thus, this finding explains that the leverage level has a negative effect on carbon emission disclosure. The results of this study support a previous study conducted by Kalu et al., (2016) which concluded that companies with low leverage levels tend to disclose more information regarding carbon emission than highly leveraged companies.

The test results indicate that the profitability of the significance value was $0.012<0.05(\alpha=5 \%)$. This finding explains that profitability affects the carbon emission disclosure (H4 is accepted). The results of this study are following Lorenzo et al. (2009) who state that companies with high profitability are more able to disclose information on carbon emissions than companies with low profitability. Companies with high profitability have more funds to pay for costs associated with collecting and reporting information related to carbon emission disclosure (Choi et al., 2013). Besides, environmental disclosure is a way to gain public trust and legitimacy to increase the company's profitability (Chithambo and Tauringana, 2014).

5.5 Results of Coefficient of Determination Test $\left(\mathbf{R}^{2}\right)$

From the results of the determination test, the adjusted $\mathrm{R}^{2}$ value was generated as follows.

Table 5.5

Coefficient of Determination Test Model Summary ${ }^{b}$

\begin{tabular}{|l|r|r|r|c|c|}
\hline Model & $\mathrm{R}$ & R Square & $\begin{array}{c}\text { Adjusted R } \\
\text { Square }\end{array}$ & $\begin{array}{c}\text { Std. Error of the } \\
\text { Estimate }\end{array}$ & Durbin-Watson \\
\hline 1 & $.410^{\mathrm{a}}$ & .168 & .144 & 0.17484 & 1.954 \\
\hline
\end{tabular}

Table 5.5 presents the results of the determination test that the adjusted $\mathrm{R}$ square value was 0.144 . This indicates that $14.4 \%$ of the company's value might be explained by the variables of company size, leverage level, and profitability while the remaining $85.6 \%$ was explained by other variables outside the model.

\subsection{Simple Linear Regression Analysis}

To investigate the effect of carbon emission disclosure on investor reaction, simple regression analysis was conducted. Then, the results of simple linear regression analysis are presented in the following table:

Table 5.6

Results of Simple Linear Regression Test Coefficients ${ }^{\mathrm{a}}$

\begin{tabular}{|c|c|c|c|c|c|}
\hline \multirow[b]{2}{*}{ Model } & \multicolumn{2}{|c|}{$\begin{array}{l}\text { Unstandardized } \\
\text { Coefficients }\end{array}$} & \multirow{2}{*}{$\begin{array}{c}\text { Standardized } \\
\text { Coefficients }\end{array}$} & \multirow[b]{2}{*}{$\mathrm{t}$} & \multirow[b]{2}{*}{ Sig. } \\
\hline & $\mathrm{B}$ & $\begin{array}{l}\text { Std. } \\
\text { Error }\end{array}$ & & & \\
\hline $1 \quad$ (Constant) & 0.024 & 0.013 & & 1.870 & 0.064 \\
\hline CED_Y & -0.012 & 0.033 & -0.037 & -0.376 & 0.707 \\
\hline
\end{tabular}

a. Dependent Variable: Z

Based on the information in table 5.6, the following regression equation is obtained.

$$
\begin{aligned}
\hline \mathrm{Z}=\boldsymbol{\alpha}+\boldsymbol{\beta}_{\mathbf{1}} \mathrm{Y}_{\mathbf{1}}+\mathbf{e} \\
\mathrm{Z}=0.024-0.012 \mathrm{Y}_{1}
\end{aligned}
$$

The Effect of carbon emission disclosure on investor reaction

Carbon emission disclosure does not affect stock returns. This can be seen from the regression coefficient value of 0.707 , greater than the significance value of 0.05 , indicating that the company's carbon emission disclosure has not been responded positively by investors seen from the company's stock price. The results of this study are opposing previous studies conducted by Ramirez et al (2016) and Liesan et al (2017) which concluded that carbon emission disclosure had a significant positive effect on stock abnormal returns. This might be due to the market 
response to the sudden implementation of carbon emission disclosure companies cannot directly affect the rate. It might require a longer time and consistent disclosure over several years.

\section{CONCLUSIONS AND SUGGESTIONS}

\subsection{Conclusions}

From the discussion in this study, the following conclusions are drawn:

1. Company size, leverage level, and profitability simultaneously affect carbon emission disclosure.

2. Company size does not affect carbon emission disclosure.

3. The leverage level has a negative effect on carbon emission disclosure.

4. Profitability affects carbon emission disclosure.

5. Carbon emission disclosure does not affect investor reaction.

\subsection{Suggestions}

From the findings of this study, the company is suggested to consider the carbon emission disclosure in the financial statements. Investors are also expected to consider the carbon emission disclosure disclosed by the company in making an investment decision. Meanwhile, the government also needs carbon emission disclosure as a consideration in making laws.

\section{REFERENCES}

Choi, Bo Bae, Doowon, Lee, and Jim Psaros. 2013. "An Analysis of Australian Company Carbon Emission Disclosures." Pacific Accounting Review Journal, Vol. 25, pp 58- 79.

Chu, Choi Ieng, Bikram Chatterjee, and Alistair Brown. 2012. The current status of greenhouse gas reporting by Chinese companies. "Managerial Auditing Journal”, Vol. 28 Iss 2 pp. 114 - 139.

Clarkson, Peter M., Yue Li, Gordon D. Richardson, Florin P. Vasvari. 2008. Revisiting The Relation Between Environmental Performance And Environmental Disclosure: An Empirical Analysis. Accounting, Organizations, and Society volume 33, Issues 4-5, Pages 303-327.

Freeman, R. E. (1984). Strategic Management: A Stakeholder Approach. Boston, MA: Pitman.

Reedman, Martin dan Bikki Jaggi. 2005. "Global warming, commitment to the Kyoto Protocol, and accounting disclosures by the largest global public firms from polluting industries", The International Journal of Accounting, Vol. 40 No. 3, pp. 21 5-232.

Dhaliwal, D. S., Li, O. Z., Tsang, A., \& Yang, Y. G. (2011). Voluntary Nonfinancial Disclosure and the Cost of Equity Capital: The Initiation of Corporate Social Responsibility Reporting. Accounting Review, 86(1), 59-100.

Ghomi \& Leung, 2013. An Empirical Analysis of The Determinants of Greenhouse Gas Voluntary Disclosure in Australia. Accounting and Finance Research, Vol. 2 No. 1, 110-127.

Ghozali, Imam dan Chariri, Anis. 2007. Teori Akuntansi. Badan Penerbit Universitas Diponegoro. Semarang.

Gray, R. (2010). Is Accounting for Sustainability Actually Accounting for Sustainability and How Would We Know? An Exploration of Narratives of Organisations and Planet. Accounting, Organizations, and Society, 35(1), 47-62the.

Gray, R. 2001. “Thirty Years of Social Accounting, Reporting, and Auditing: what (if anything) have we learnt?.’Business Ethics: A European Review, Vol. 10, No.1, pp. 9-15.

Gupta, K. (2018). Environmental Sustainability and Implied Cost of Equity: International Evidence. Journal of Business Ethics, 147(2), 343-365.

Harrison, J. S., \& Wicks, A. C. (2013). Stakeholder Theory, Value, and Firm Performance. Business Ethics Quarterly, 23(1), 97-124. 
Kartini, Dwi. 2013. Corporate Social Responsibility: Tranformasi Konsep Sustainablity Management dan Implementasi di Indonesia. Bandung: Refika Aditama.

Kalu, J. U., Buang, A.,\& Aliagha, G. U.(2016). Determinants of Voluntary Carbon Disclosure in The Corporate Real Estate Sector of Malaysia. Journal of Environmental Management, 182, 519-524. https://doi.org/10.1016/j.jenvman.2016.08.011

Kelvin, C., Daromes, F., \& Ng, S. (2017). Pengungkapan Emisi Karbon sebagai Mekanisme P eningkatan Kinerj a untuk Menciptakan Nilai Perusahaan. Dinamika Akuntansi Keuangan Dan Perbankan, 6(1), 1-18. Retrieved from

Larocque, S., \& Lyle, M. R. (2017). Implied Cost of Equity Capital Estimates as Predictors of Accounting Returns and Stock Returns. Journal of Financial Reporting Spring 2017, 2(1), 69-93

Li, B., \& Wu, K. (2017). The Price of Environmental Sustainability: Empirical Evidence from Stock Market Performance in China. Sustainability (Switzerland), 9(8), 1-16

Li, Y., Ng, D. T., \& Market Returns Using Aggregate Implied Cost of Capital. Journal of Financial Economics, 110(2), 419-436.Swaminathan, B. (2013). Predicting

Lorenzo, D., Fiechter, J., Schneider, N., Bracco, A., Miller, A. J., Franks, P. J. S., Bograd, S. J., Moore, A. M., Thomas, A. C., Crawford, W., Pen a, A., \& Hermann, A. J. (2009). Nutrient and Salinity Decadal Variations in The Central and Eastern North Pacific. Geophysical Research Letters,36(L14601), 1-6. doi:10.1029/2009GL038261

Liesen, A., Figge, F., Hoepner, A., \& Patten, D. M.(2017). Climate Change and Asset Prices: AreCorporate Carbon Disclosure and PerformancePriced Appropriately? Journal of Business Finance and Accounting, 44(1-2), $35-62$

Lovelock, J. E. (1979). Gaia: A New Look at Life on Earth. Oxford: Oxford University Press.

Liao, L., Luo, L., \& Tang, Q. (2015). Gender Diversity, Board Independence, Environmental Committee, and Greenhouse Gas Disclosure. British Accounting Review, 47(4), 409-424.

Liesen, A., Figge, F., Hoepner, A., \& Patten, D. M. (2017). Climate Change and Asset Prices: Are Corporate Carbon Disclosure and Performance Priced Appropriately? Journal of Business Finance and Accounting, 44(12), $35-62$

Luo, Le, Qingliang Tang, Yi-Chen Lan. (2012). Corporate Incentives to Disclosure Carbon Information: Evidence From CDP Global 500 Report. Journal of International Financial Management and Accounting. Volume 23 No. 2. Hal 93-120.

Luo, Le, Qingliang Tang, Yi-chen Lan. (2013). Comparison of Propensity for Carbon Disclosure between Developing and Developed Countries. Accounting Research Journal Vol. 26 No. 1, 2013 pp. 6-34.

Meng, X. H., Zeng, S. X., Shi, J. J., Qi, G. Y., \& Zhang, Z. B. (2014). The Relationship Between Corporate Environmental Performance and Environmental Disclosure: An Empirical Study in China. Journal of Environmental Management, 145, 357-367.

Michaels, A., \& Grüning, M. (2017). Relationship of Corporate Social Responsibility Disclosure on Information Asymmetry and the Cost of Capital. Journal of Management Control, 28(3), 251-274.

Prado-Lorenzo, J.M., Rodríguez-Domínguez, L., Gallego-Álvarez, I. and García-Sánchez, I.M. (2009), "Factors influencing the disclosure of greenhouse gas emissions in companies world-wide", Management Decision, Vol. 47 No. 7, pp. 1133-1157

Pradini, Harlinda Siska dan Endang Kiswara (2013). The Analysis of Information Content Towards Greenhouse Gas Emission Disclosure in Indonesia Companies. Diponegoro Journal Of Accounting. Volume 2 No. 2. 
Hal. 1-12.

Ramírez, C. Z., González-González, J. M., \& SabaterMarcos, A. (2016). Carbon Reporting/ : Analysis of the Spanish Market Response. Spanish Journal of Finance and Accounting, 45(2), 231-265.

Spence, M. (1973). Job Market Signaling. The Quarterly Journal of Economics, 87(3), 355-374.

Tauringana, Venancio dan Lyton Chitambo. (2014). The Effect of DEFRA Guidance On Greenhouse Gas Disclosure. The British Accounting Review. Hal 1-20.

Zhang, Shan, et al. (2012). Australian Corporate Responses to Climate Change: The Carbon Disclosure Project. The RMIT Accounting for Sustainability Conference. Hal 1-32 